\title{
Model Sistem Peran Teknologi Dan Informasi Terhadap Pertahanan Bisnis Di Indonesia
}

\section{Tati Herlia}

Analis Pertahanan Negara Madya Set Balitbang Kemhan

Email : tatiherlia@yahoo.co.id

\begin{tabular}{ll}
\hline ARTICLE INFO & ABSTRACT \\
\hline Keywords: & $\begin{array}{l}\text { Business is an activity carried out and carried out by someone or a group of people or } \\
\text { companies in the form of services or goods to obtain profits or profits. Nowadays } \\
\text { System model, } \\
\text { Role of Technology and } \\
\text { Information, }\end{array} \quad \begin{array}{l}\text { economy industry sector. Creative economy is an economy that is based on high } \\
\text { Defense of Indonesian } \\
\text { Business }\end{array}$ \\
Today's business trends are more companies in the creative economy. This is because \\
the creative economy is faster than other industries. The fastest growing creative \\
industry and development is in the field of information technology. The cause of the \\
creative industry in the field of technology is growing rapidly, because the world is \\
now entering the information technology era. So today's business does not recognize \\
space and time. In addition, business is easy to do and easily accepted by consumers. \\
This, if left unchecked, will disrupt national economic stability so that it is necessary to \\
make a System Model for the Role of Information Technology towards Business \\
Defense in Indonesia.
\end{tabular}

\section{PENDAHULUAN}

Teknologi Informasi dan Komunikasi (TIK) saat ini sudah dimanfaatkan pada semua aspek kehidupan masyarakat di dunia. Hal tersebut mendorong terbentuknya satu komunitas yang terhubung secara elektronik dalam satu ruang yang sering disebut ruang siber (cyber space). Pemanfaatan sistem elektronik termasuk jaringan internet digunakan untuk mendukung berbagai kegiatan di sektor usaha, perdagangan, layanan kesehatan, komunikasi dan kepemerintahan, serta sektor pertahanan.

Peningkatan pemanfaatan internet tersebut, juga meningkatkan ancaman, antara lain upaya pembobolan kerahasiaan informasi, perusakan sistem elektronik dan perbuatan melawan hukum lainnya. Sehingga, ruang siber perlu mendapatkan perlindungan yang layak agar menghindari potensi yang dapat merugikan pribadi, organisasi bahkan negara.

Istilah pertahanan siber timbul sebagai upaya untuk melindungi diri dari ancaman dan gangguan tersebut, dengan ruang lingkup bertingkat, dari lingkup perorangan, kelompok kerja, organisasi sampai dengan skala nasional. Pada sektor yang mengelola infrastruktur kritis seperti pertahanan keamanan, energi, transportasi, sistem keuangan, dan berbagai layanan publik lainnya, perlu diberi perhatian khusus. Pada sistem elektronik pada sektor-sektor tersebut, gangguan yang terjadi dapat menyebabkan kerugian ekonomi, turunnya tingkat kepercayaan kepada pemerintah, terganggunya ketertiban umum dan lain lain. Timbulnya risiko inilah yang menjadi pertimbangan diperlukannya pertahanan siber yang kuat dalam sebuah negara.

Urgensi pertahanan siber ditujukan untuk mengantisipasi datangnya ancaman ancaman dan serangan siber yang terjadi dan menjelaskan posisi ketahanan saat ini, sehingga diperlukan kesiapan dan ketanggapan dalam menghadapi ancaman serta memiliki kemampuan untuk memulihkan akibat dampak serangan yang terjadi di ranah siber.

Pertahanan bisnis (cyber defense) adalah suatu upaya untuk menanggulangi serangan bisnis yang menyebabkan terjadinya gangguan terhadap penyelenggaraan ekonomi kreatif. 


\section{METODE}

Tulisan ilmiah ini menggunakan metode kualitatif dengan teknik deskriptif analitis. Adapun teknik pengumpulan datanya melalui studi pustaka dengan penelusuran terhadap sumber-sumber tertulis. Sumber pokok adalah buku-buku literatur, tulisan ilmiah serta laporan-laporan yang memuat konten Peran Teknologi Informasi terhadap Pertahanan Indonesia.

\section{ANALISIS DAN PEMBAHASAN}

Perkembangan teknologi informasi (TI) yang sangat pesat telah mengubah gaya hidup individu dan mengubah cara organisasi menjalankan bisnis. TI menjadikan segala suatu aktivitas menjadi lebih cepat, mudah, dan akurat. Peranan TI dalam industri kreatif sangat dominan. TI menjadi kontributor utama pendukung pertumbuhan dari sebuah industri kreatif dan daya dorong perkembangan ekonomi nasional yang dapat meningkatkan daya saing industri Indonesia dalam persaingan global.

\section{Teknologi Informasi}

Teknologi informasi (TI) adalah sebagai studi, perancangan, pengembangan, implementasi, dukungan atau pengelolaan sistem informasi berbasis komputer, khususnya aplikasi perangkat lunak dan perangkat keras komputer. TI berhubungan dengan penggunaan komputer dan perangkat lunak untuk mengubah, menyimpan, memproteksi, memproses, menyampaikan, mengambil informasi secara aman.

Saat ini sangat tidak mungkin untuk melakukan kegiatan usaha atau bisnis tanpa bantuan komputer. TI sebagai kontributor utama bagi kemajuan negara maju maupun negara berkembang. Hal tersebut telah mengubah secara drastis lansekap bisnis di seluruh dunia, dan kata TI (teknologi informasi) menjadi "catchword" bagi kehidupan modern saat ini. Perkembangan terkini dalam TI telah mengubah cara organisasi menjalankan kegiatannya. Implementasi TI memberikan dampak positif terhadap sektor ekonomi. Dampak positif ini dibuktikan dengan ukuran atau indikator kinerja kualitatif. Peningkatan yang signifikan terlihat pada beberapa indikator seperti kepuasan pelanggan, hubungan pelanggan atau pemasok, citra perusahaan, tingkat keyakinan stakeholder, dan komunikasi antar kantor.

\section{Peran Teknologi Informasi (TI).}

TI berperan sangat besar dalam berbagai organisasi. Peranan TI dalam organisasi dapat berupa support, enabler, maupun business drivers. Peranan TI sebagai support dalam arti bahwa teknologi informasi mendukung segala aktivitas organisasi atau kegiatan bisnis agar dapat berjalan dengan cepat, akurat, dan mudah. Sebagai enabler, teknologi informasi memberikan solusi-solusi baru dalam menyelesaikan persoalan yang dihadapi organisasi. Sedangkan sebagai business drivers, teknologi informasi menjadi main/ core business dalam aktivitas organisasi dalam arti memberikan arah baru dalam bisnis organisasi/ perusahaan.

\section{Industri Kreatif}

Definisi Industri Kreatif yang saat ini banyak digunakan oleh pihak yang berkecimpung dalam industri kreatif, : "Creative industries as those industries which have their origin in individual creativity, skill \& talent, and which have a potential for wealth and job creation through the generation and exploitation of intellectual property and content".

Studi pemetaan industri kreatif yang telah dilakukan oleh Departemen Perdagangan Republik Indonesia tahun 2007 pun menggunakan acuan definisi industri kreatif yang sama, sehingga industri kreatif di Indonesia dapat didefinisikan sebagai berikut :

"Industri yang berasal dari pemanfaatan kreativitas, ketrampilan serta bakat individu untuk penciptaan kesejahteraan serta lapangan pekerjaan melalui penciptaan dan pemanfaatan daya kreasi dan daya cipta individu tersebut".

Industri kreatif adalah bagian tak terpisahkan dari ekonomi kreatif. Republik Indonesia menyadari bahwa ekonomi kreatif, yang berfokus pada penciptaan barang dan jasa dengan mengandalkan keahlian, bakat, dan kreativitas sebagai kekayaan intelektual adalah harapan bagi ekonomi Indonesia untuk bangkit, bersaing dan meraih keunggulan dalam ekonomi global. Di Indonesia, peran industri kreatif dalam ekonomi Indonesia cukup signifikan dengan besar kontribusi terhadap PDB rata-rata tahun 2002-2006 adalah sebesar 
6,3\% atau setara dengan 104,6 triliun rupiah (nilai konstan) dan 152,5 triliun rupiah (nilai nominal). Industri ini telah mampu menyerap tenaga kerja rata-rata tahun 2002-2006 adalah sebesar 5,4 juta dengan tingkat partisipasi sebesar $5,8 \%$.

Untuk mengembangkan ekonomi kreatif ini, diyakini bahwa kolaborasi antara berbagai aktor yang berperan dalam industri kreatif yaitu Cendikiawan (Intellectuals), Bisnis (Business), dan Pemerintah (Government ) menjadi mutlak dan merupakan prasyarat mendasar. Tanpa kolaborasi antara elemen I-B-G ini, maka dikhawatirkan bahwa pengembangan ekonomi kreatif tidak berjalan selaras, efisien, dan saling tumpang tindih.

Ada tiga pilar utama yang menjalin terbentuknya Masyarakat Industri Kreatif Teknologi Informasi \& Komunikasi Indonesia (MIKTI). Tiga pilar tersebut pertama adalah Industri-Ekonomi Kreatif yang telah menjadi acuan pengembangan utama di Departemen Perindustrian maupun Perdagangan, kedua adalah memperpanjang kemampuan Industri Kreatif tersebut dengan memanfaatkan keunggulan TIK dan ketiga adalah pilar Budaya sebagai upaya melibatkan secara langsung masyarakat kreatif, sebagai daya dorong, sekaligus sebagai faktor pembeda nyata yang unik dalam persaingan global.

Industri Kreatif merupakan Industri yang bermuara pada intelektualitas, ide dan gagasannya yang orisional, kemudian merealisasikan berdasarkan pemikiran dan rasa dari lubuk hati yang paling dalam sebagai insan kreatif yang ingin memajukan industry dalam negeri. Total dari aktifitas Ristek merupakan bagian klaster industri kreatif, salah satunya riset dan pengembangan (R\&D). Seluruh aktifitas Ristek yang melakukan Riset merupakan unsur kreatifitas. Terkait dengan program ristek, pengembangan 6 bidang focus iptek termasuk kategori kreatif, misalnya industri kreatif berkaitan sangat spesial dengan TI, antara lain bagaimana menjadikan kreatifitas agar bernilai ekonomi, contoh: software, animation, dan game on line. Dalam hal inilah terlihat peran tripple helix (Akademisi, Business, Government atau ABG) pada industri kreatif. Bagaimana 3 komponen tersebut saling bersinergi, berinteraksi untuk menghasilkan suatu produk kreatif yang punya nilai ekonomi.

Hal serupa juga disampaikan oleh Intel Capital Director-South East Asia-Intel Asia Pasific, Deepak Natarajan bahwa industri kreatif harus didorong oleh regulasi pajak yang baik. Pemerintah Indonesia menurutnya harus memberikan kemudahan bagi para pelaku bisnis industry kreatif dalam mendapatkan investasi dan penjualan produk. Jika regulasi ini tertata dengan baik bukan tidak mungkin akan banyak pelaku investasi yang tertarik.

Investasi memiliki beberapa kriteria penting, di antaranya melayani pasar yang belum terlayani, tim manajemen yang berpengalaman, significant barriers to entry, financial attractiveness, dan intel value-add.

Saat ini, inovasi investasi global sedang mengarah ke sektor pengguna internet. Perkembangan pesat industri kreatif yang terjadi di seluruh dunia saat ini menuju kearah media online. Hal sangat penting saat ini, terutama untuk industri kreatif adalah mermpercepat broadband connection."

Untuk perkembangan industri kreatif, 230 juta penduduk Indonesia, merupakan potensi pasar yang cukup besar. Potensi ini seharusnya didorong dengan perbaikan fasilitas yang harus dilakukan oleh pemerintah dalam waktu singkat.

\section{Peran Teknologi dalam Industri Kreatif.}

Perkembangan bidang TI, ilmu pengetahuan dan kreativitas telah memicu lahirnya wacana mengenai industri kreatif yang saat ini telah menjadi fenomena global. Selain di negara maju, perkembangan industri kreatif setidaknya juga tumbuh secara pesat di beberapa negara berkembang seperti China, India, Brasil, Argentina, Meksiko, bahkan Burkina Faso yang terletak didaratan Afrika.

Sektor ekonomi kreatif ini memberikan sumbangan GNP sebesar 3 persen. Lebih lanjut Sultan mencontohkan, di Inggris dan Belanda, sector ekonomi kreatif tercatat memberikan kontribusi bagi penciptaan lapangan kerja baru sampai sebesar 30 persen. Sementara di Indonesia, perkembangan sektor ekonomi kreatif juga tengah berkembang pesat di beberapa kota besar selama kurun waktu 10 tahun terakhir.

Dalam industri kreatif khususnya peranan teknologi informasi menjadi dominan dalam menghasilkan karya kreatif. Diantara 13 kelompok industri kreatif, setidaknya 10 industri sangat terkait erat dengan teknologi informasi. Industri tersebut yaitu industri periklanan, arsitektur, disain, video, film dan 
fotografi, permainan interaktif (game), musik, penerbitan dan percetakan, layanan komputer dan piranti lunak, televisi dan radio, juga riset dan pengembangan.

Tersedianya piranti keras sebagai pendukung utama subsektor industri kreatif dalam mengolah data, memproduksi, pasca produksi dan distribusi. Perkembangan teknologi processor ini menawarkan kemudahan-kemudahan yang dapat dinikmati dalam proses pembuatan menjadi lebih cepat dan tingkat kualitas yang dihasilkan lebih baik.

\section{Industri Kreatif yang Sangat Erat dengan Teknologi}

1. Periklanan. Kegiatan kreatif yang berkaitan dengan kreasi dan produksi iklan, antara lain: riset pasar, perencanaan komunikasi iklan, iklan luar ruang, produksi material iklan, promosi, kampanye relasi publik, tampilan iklan di media cetak dan elektronik.

2. Arsitektur. Kegiatan kreatif yang berkaitan dengan cetak biru bangunan dan informasi produksi antara lain: arsitektur taman, perencanaan kota, perencanaan biaya konstruksi, konservasi bangunan warisan, dokumentasi lelang, dan lain-lain.

3. Pasar Seni dan Barang Antik. Kegiatan kreatif yang berkaitan dengan kreasi dan perdagangan, pekerjaan, produk antik dan hiasan melalui lelang, galeri, toko, pasar swalayan, dan internet.

4. Kerajinan. Kegiatan kreatif yang berkaitan dengan kreasi dan distribusi produk kerajinan antara lain barang kerajinan yang terbuat dari batu berharga, aksesoris, pandai emas, perak, kayu, kaca, porselin, kain, marmer, kapur, dan besi.

5. Desain. Kegiatan kreatif yang terkait dengan kreasi desain grafis, interior, produk, industri, pengemasan, dan konsultasi identitas perusahaan.

6. Desain Fesyen. Kegiatan kreatif yang terkait dengan kreasi desain pakaian, desain alas kaki, dan desain aksesoris mode lainnya, produksi pakaian mode dan aksesorisnya, konsultansi lini produk fesyen, serta distribusi produk fesyen. Sebagai contoh Batik.

7. Video, Film dan Fotografi. Kegiatan kreatif yang terkait dengan kreasi produksi video, film, dan jasa fotografi, serta distribusi rekaman video, film. Termasuk didalamnya penulisan skrip, dubbing film, sinematografi, sinetron, dan eksibisi film.

8. Permainan Interaktif. Kegiatan kreatif yang berkaitan dengan kreasi, produksi, dan distribusi permainan komputer dan video yang bersifat hiburan, ketangkasan, dan edukasi. Sebagai contoh game nusantara online. Game ini merupakan sebuah game online dengan genre MMORPG (Masiv Multiplayer Online Role Playing Game). Game online ini merupakan karya anak bangsa dengan latar belakang sejarah nusantara masa lalu.

9. Musik. Kegiatan kreatif yang berkaitan dengan kreasi, produksi, distribusi, dan ritel rekaman suara, hak cipta rekaman, promosi musik, penulis lirik, pencipta lagu atau musik, pertunjukan musik, penyanyi, dan komposisi musik.

10. Seni Pertunjukan. Kegiatan kreatif yang berkaitan dengan pengembangan konten, produksi pertunjukan, pertunjukan balet, tarian tradisional, tarian kontemporer, drama, musik tradisional, musik teater, opera, termasuk tur musik etnik, desain dan pembuatan busana pertunjukan, tata panggung, dan tata pencahayaan.

11. Penerbitan \& Percetakan. Kegiatan kreatif yang terkait dengan dengan penulisan konten dan penerbitan buku, jurnal, koran, majalah, tabloid, dan konten digital serta kegiatan kantor berita.

12. Layanan Komputer dan Piranti Lunak. Kegiatan kreatif yang terkait dengan pengembangan teknologi informasi termasuk jasa layanan komputer, pengembangan piranti lunak, integrasi sistem, desain dan analisis sistem, desain arsitektur piranti lunak, desain prasarana piranti lunak dan piranti keras, serta desain portal.

13. Televisi \& Radio. Kegiatan kreatif yang berkaitan dengan usaha kreasi, produksi dan pengemasan, penyiaran, dan transmisi televisi dan radio. 
14. Riset dan Pengembangan. Kegiatan kreatif yang terkait dengan usaha inovatif yang menawarkan penemuan ilmu dan teknologi dan penerapan ilmu dan pengetahuan untuk perbaikan produk dan kreasi produk baru, proses baru, material baru, alat baru, metode baru, dan teknologi baru yang dapat memenuhi kebutuhan pasar. Sebagai contoh riset dan pengembangan karya anak bangsa seperti :

a. MOSES (Malaria Observation System and Endemic Surveillance). MOSES merupakan sistem mikroskop digital yang memanfaatkan kamera di ponsel untuk meneliti darah dan kemudahan mengetahui ada atau tidaknya gejala malaria. Inovasi baru ini diciptakan oleh tim Big Bang dari Institut Teknologi Bandung (ITB) yang telah menjuarai Image Cup 2009.

b. JBatik (Batik Fracal). Ini merupakan seni batik tradisional yang dibuat dari perpaduan antara seni, ilmu sains dan teknologi. JBatik ini diciptakan oleh Pixel People Project.

\section{Pengertian Bisnis.}

Bisnis adalah suatu aktivitas yang dilakukan dan dijalankan oleh seseorang atau sekelompok orang ataupun perusahaan dalam bentuk jasa atau barang untuk memperoleh laba atau keuntungan.

Saat ini perkembangan bisnis berjalan dengan cepat karena adanya teknologi informasi yang semakin canggih. Selain itu bisnis dapat berkembang dengan cepat, jika memiliki produk dan jasa yang mempunyai karakteristik dan inovasi yang berbeda dibandingkan produk atau jasa yang lain. Bisnis dapat dikatakan berhasil apabila berkontribusi positif bagi peningkatan kualitas dan standar hidup masyarakat, terlibat dalam kegiatan amal, menghasilkan pemimpin bagi masyarakat dan menjadi contoh-contoh bagi bisnis lainnya.

\section{Perkembangan Bisnis di Indonesia.}

Saat ini para pengusaha di Indonesia mulai membangun dan menjalankan bisnis mengikuti sesuai perkembangan jaman. Hal ini perlu dilakukan suatu perusahaan agar bisa bertahan tanpa tergerus jaman, selain itu jika suatu perusahaan mengikuti perkembangan jaman, maka perusahaan akan berkembang lebih cepat. Dunia bisnis sudah beberapa kali mengalami pergantian masa, mulai dari era kolonial hingga era informasi sekarang.

Perkembangan bisnis di Indonesia dari masa ke masa :

a. Era Kolonial Era kolonial dimulai pada abad ke-17 dan sebelumnya. Pada masa ini usaha yang dilakukan masih terkait dengan produksi pertanian dan perkebunaan di pedesaan di mana aspek ekonominya ditentukan oleh sukses tidakya pertanian dan produksi tersebut.

b. Revolusi Industri Era revolusi industri dimulai pada tahun 1760-1850, pada masa ini usaha mulai menggunakan mesin untuk memproduksi massal produk-produk yang dibuat. Pekerja manual banyak digantikan perannya dengan menggunakan mesin-mesin dan alat-alat khusus untuk memproduksi produk dengan cepat.

c. Era Kewirausahaan Era kewirausahaan dimulai saat akhir tahun 1800-an, pada masa ini mulai bermunculan para pengusaha baru sebagai reaksi atas ditolaknya sistem monopoli yang merajalela pada masa itu oleh para pengusaha-pengusaha besar dan adanya undang-undang antitrust.

d. Era Produksi Era produksi dimulai sebelum tahun 1920-an, ahli organisasi bisnis dengan konsep Scientific Management mengarahkan manajemen perusahaan untuk fokus pada proses produksi melalui spesialisasi tugas dan peningkatan produktivitas.

e. Era Pemasaran Era pemasaran dumulai sejak 1950-an, pada masa ini berkembang filosofi bisnis baru berupa konsep pemasaran yang membentuk kesadaran, prefensi serta selera konsumen dan didasarkan atas keinginan pelanggan dan kemudian perusahaan menyediakannya.

f. Era Global Era global dimulai pada tahun 1980-an, pada masa ini usaha merambah ke berbagai belahan dunia akibat kemudahan transportasi dan kemajuan teknologi computer, sistem informasi, sitem produksi serta semakin efisiennya sistem distribusi dan pembiayaan internasional.

g. Era Informasi Era informasi dimulai pada tahun 1990-an, pada masa ini mulai tingginya pengguna internet yang memudahkan perdagangan di semua sektor perekonomian maupun sektor jasa serta 
menjadi sarana yang mudah dan cepat dalam proses business to business. Teknologi informasi telah mengubah wajah dunia dan aktivitas bisnis demikian dinamisnya tanpa terhalang ruang dan jarak. Aplikasi e-commerce, e-government, e-banking, e-education, dan berbagai aplikasi lainnya merupakan bagian tak terpisahkan dari sistem bisnis di era informasi. Komunikasi bisnis berlangsung secara online melalui internet dengan biaya relatif murah dibandingkan degan pola konvensional, seperti e-mail, mailing list, dan pembuatan homepage atau situs perusahaan untuk memperkenalkan perusahaan teknologi computer, sistem informasi, sitem produksi serta semakin efisiennya sistem distribusi dan pembiayaan.

\section{Manfaat Teknologi Informasi (TI).}

Saat ini TI atau Teknologi Informasi dapat membantu suatu bisnis untuk menjadi lebih responsif, efisien dan fleksibel dalam wujud perubahan yang cepat dan keberlanjutan. Jika suatu perusahaan memanfaatkan TI dengan tepat aakan membuat suatu perusahaan mempercepat proses dan fokus pada inti keahliaan dan kemampuan yang membedakannya dari pesaingnya yang berada di pasaran. Suatu perusahaan akan memiliki perkembangan yang cepat apabila menggunakan TI dalam lingkup perusahaannya.

Menggunakan kekuatan sistem TI di zaman modern saat ini merupakan kebutuhan penting dalam suatu bisnis agar bisnis dapat bersaing dengan komptetitor bisnis lainnya. Beberapa Fungsi TI dalam bisnis bisa digunakan agar TI dapat membuat kita lebih dekat dengan konsumen, TI dapat membantu kita untuk menurunkan biaya. TI dapat membantu kita agar lebih fleksibel. Apabila sebuah bisnis menggunakan sistem teknologi informasi dalam ruang lingkup perusahaanya, maka ada beberapa hal yang harus diperhatikan agar sistem yang berjalan dalam perusahaan efektif,yaitu transparan pada pengguna; pengguna tidak perlu tahu bagaimana sistem bekerja, persyaratannya sederhana bahwa mereka dapat digunakan sesuai kebutuhan dan pada saat dibutuhkan.

Cepat dan mudah untuk digunakan, pengguna harus menemukan sistem yang sederhana untuk digunakan, dan harus menunggu waktu yang lama untuk sistem dapat merespons. Fleksibel, perubahan membutuhkan sistem dengan syarat mampu diadaptasikan dengan cepat.

\section{Persaingan Bisnis.}

Bentuk persaingan pasar dikategorikan atas empat macam, yaitu :

a. Monopoli, terjadi ketika pasar atau industry hanya memiliki satu produsen sehingga harga dikendalikan sepenuhnya oleh pemasok tunggal.

b. Oligopoli, terjadi karena dalam suatu industry hanya terdapat sedikit penjualan karena untuk masuk ke industry tersebut butuh investasi yang besar.

c. Persaingan Monopolistik Persaingan monopolistik terjadi pada persuhaan skala besar atau kecil di mana perusahaan lebih mudah untuk masuk atau keluar dari pasar tersebut. Biasanya perusahaan di persaingan monopolistik menciptakan diferensiasi untuk produknya.

d. Persaingan Sempurna Persaingan sempurna terjadi apabila jumlah perusahaan dalam suatu industri banyak dan berskala kecil sehingga tidak terdapat perusahaan yang mempengaruhi harga pasar.

\section{Sumber Ancaman dan Serangan TI dalam Pertahanan Bisnis di Indonesia.}

Bisnis yang ada di Indonesia dikaitkan dengan peran TI sebagai support, enabler, maupun business drivers tidak terlepas dari ancaman dan serangan. Sumber Ancaman dalam dunia bisnis TI antara lain adalah entitas yang berkeinginan atau memiliki niat dan benar-benar secara nyata akan melakukan kegiatan yang melanggar norma dan hukum, aturan dan ketentuan serta kaidah atau kontrol keamanan informasi serta aset fisik lainnya, dengan tujuan untuk mendapatkan keuntungan pribadi ataupun kelompok tertentu. Secara umum unsur-unsur yang dapat diidentifikasi memiliki potensi sebagai sumber ancaman dapat berasal dari sumber internal dan eksternal perusahaaan bisnis di Indonesia itu sendiri, adanya kegiatan intelijen, kekecewaan, investigasi, organisasi ekstremis, hacktivists, grup kejahatan terorganisir, persaingan, permusuhan dan konflik serta teknologi.

Serangan pada perusahaan bisnis di Indonesia juga meliputi antara lian serangan jenis Advanced Persistent Threats (APT), Denial of Service (DoS) dan Distributed Denial of Service (DDoS), biasanya 
dilakukan dengan melakukan overloading kapasitas sistem dan mencegah pengguna yang sah untuk mengakses dan menggunakan sistem atau sumber daya yang ditargetkan. Serangan ini bertujuan untuk mengganggu operasional sistem, dengan cara menghadapkan sistem pada permintaan akses dan proses yang jauh lebih besar dari yang bisa ditangani sistem. Sehingga sistem menjadi terlalu sibuk dan crash, akibatnya menjadi tidak dapat melayani atau tidak dapat beroperasi. Permasalahan ini merupakan ancaman yang berbahaya bagi organisasi yang mengandalkan hampir sepenuhnya pada kemampuan internet guna menjalankan roda kegiatannya.

Serangan Defacement, dilakukan dengan cara melakukan penggantian atau modifikasi terhadap halaman web korban sehingga isi dari halaman web korban berubah sesuai dengan motif penyerang.

Serangan Phishing, dilakukan dengan cara memberikan alamat website palsu dengan tampilan persis sama dengan website aslinya. Tujuan dari serangan phishing ini adalah untuk mendapatkan informasi penting dan sensitif seperti username, password dan lain-lain.

Serangan Malware, yaitu suatu program atau kode berbahaya yang dapat digunakan untuk mengganggu operasi normal dari sebuah sistem komputer. Biasanya program malware telah dirancang untuk mendapatkan keuntungan finansial atau keuntungan lain yang direncanakan. Jumlah serangan malware terus berkembang, sehingga saat ini telah menjadi pandemi yang sangat nyata. Malware telah terjadi dimana-mana dan mempengaruhi semua orang yang terlibat dalam setiap sektor kegiatan. Istilah virus generik digunakan untuk merujuk setiap program komputer berbahaya yang mampu mereproduksi dan menyebarkan dirinya sendiri.

Penyusupan siber, yang dapat menyerang sistem melalui identifikasi pengguna yang sah dan parameter koneksi seperti password, melalui eksploitasi kerentanan yang ada pada sistem. Metode utama yang digunakan untuk mendapatkan akses ke dalam system. adalah dengan cara Menebak Sandi yang begitu jelas, seperti nama pengguna, nama pasangan atau anak, tanggal lahir atau berbagai yang penting yang berkaitan dengan diri dan keluarganya, sangat mudah untuk ditebak dan dipecahkan; Account yang tidak terlindungi. Pengguna juga dapat melakukan kesalahan, dengan tidak memasang password atau dengan mudah memberikan password kepada orang lain; Penipuan dan Rekayasa Sosial, misalnya pelaku dapat mengaku dan bertindak sebagai administrator dan meminta password dengan beberapa alasan teknis. Dalam sejumlah besar kasus, pengguna akan mengungkapkan data mereka. Pelaku dapat menipu melalui telepon atau pesan elektronik. Beberapa orang pelaku tidak faham komputer, tetapi ternyata pelaku dapat memperoleh kunci sesuai dengan sistem yang mereka inginkan untuk ditembus; mendengarkan lalu lintas komunikasi data. Penyadap akan mendengarkan data yang tidak terenkripsi yang dikirimkan melalui jaringan melalui protokol komunikasi. Mereka beroperasi menggunakan $P C$ dengan cara mengendus (sniffing) dan menganalisis data dalam transit di jaringan, kemudian mengekstraksi password terenkripsi yang ditularkan oleh pengguna selama koneksi. Jika pelaku tidak bisa mengandalkan keterlibatan dari dalam organisasi dalam mendapatkan password secara langsung, maka dengan bantuan perangkat elektronik mereka dapat mencegatnya dari protokol komunikasi atau mengakses file yang berisi semua password.

Trojan Horse, program mata-mata yang spesifik dan sangat berbahaya (spyware) secara diam-diam dapat merekam parameter yang digunakan untuk menghubungkannya ke sistem remote.

\section{Penanggulangan Gangguan dan Serangan TI untuk pertahanan Bisnis di Indonesia.}

Pertahanan TI (cyber defense) untuk pertahanan bisnis di Indonesia adalah suatu upaya untuk menanggulangi serangan TI yang menyebabkan terjadinya gangguan terhadap penyelenggaraan bisnis di Indonesia secara normal. Pertahanan TI disiapkan sebagai suatu upaya penanggulangan terhadap gangguan dan serangan TI sebagai berikut :

a. Penanganan secara hukum. Melakukan koordinasi dengan aparat keamanan terkait apabila telah diketahui pelaku kejahatan TI.

b. Serangan balik TI (Cyber counter-attack), adalah suatu tindakan serangan balik terhadap sumber serangan dengan tujuan memberikan efek jera terhadap pelaku serangan TI.

Sasaran Serangan TI berdasarkan tujuan dan sasarannya ditujukan kepada Perorangan, masyarakat umum, organisasi, komunitas tertentu, yang bersifat kejahatan TI, Obyek Vital Infrastruktur Bisnis yaitu 
sistem-sistem infrastruktur fisik dan non fisik TI yang sangat penting dimana bila sistem ini tidak berfungsi atau rusak, maka dapat berdampak melemahkan bisnis di Indonesia.

Persiapan untuk penyediaan SDM dalam rangka mendukung pertahanan TI dalam bisnis di Indonesia sudah mulai dilakukan, meskipun baru persiapan awal dalam bentuk program peningkatan kesadaran (awareness) dan peningkatan pengetahuan dan keterampilan keamanan informasi. Implementasi Pertahanan TI pada masa yang akan datang akan memerlukan program peningkatan SDM yang jauh lebih besar dan substantif.

Model Sistem kebutuhan kompetensi berkaitan erat dengan jenjang karir bagi Pengawak dalam memainkan Peran TI terhadap Pertahanan Bisnis di Indonesia, dapat digambarkan secara umum sebagai berikut :

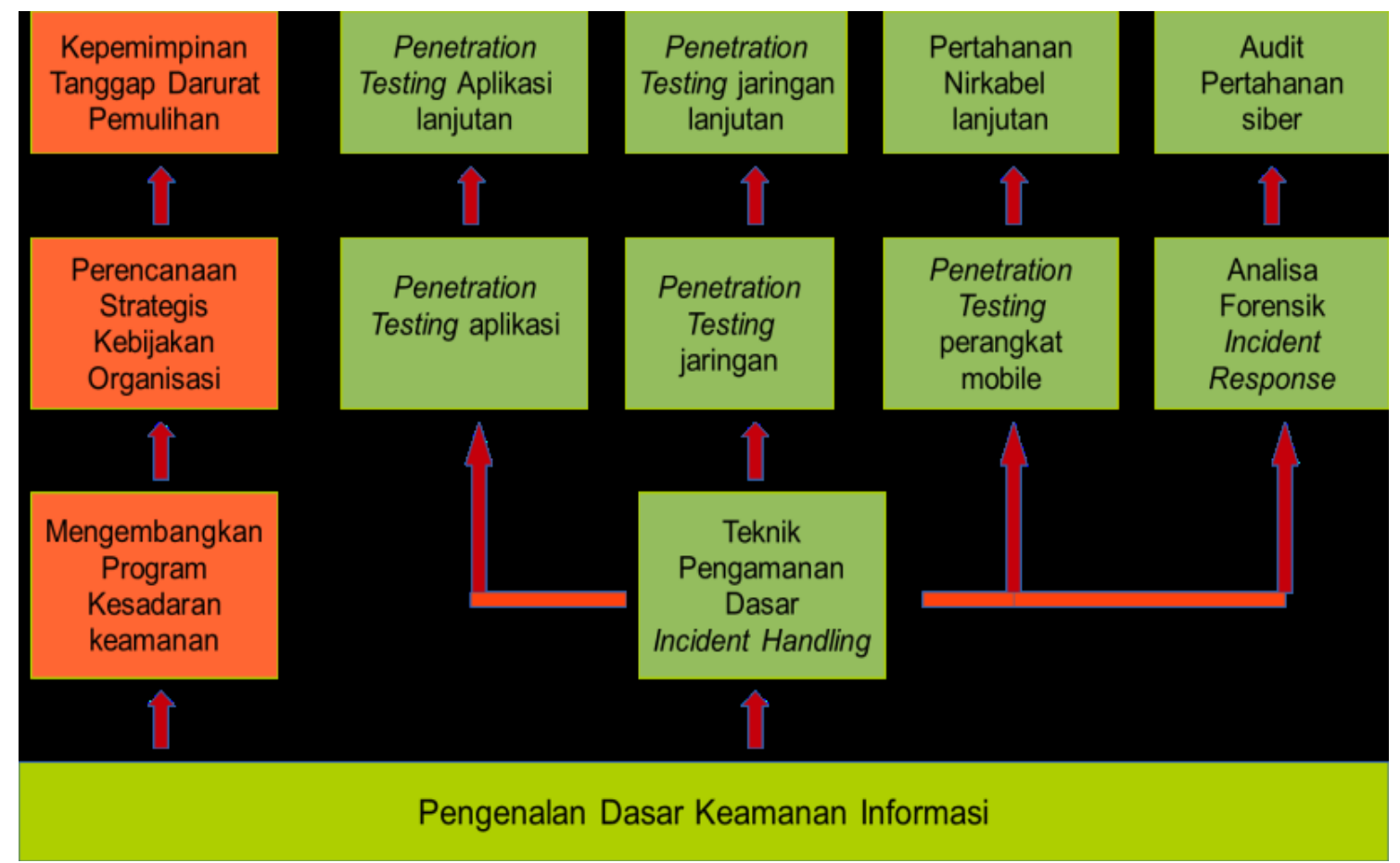

Gambar 1. Model Sistem Peran TI terhadap Pertahanan Bisnis di Indonesia melalui Pengenalan Dasar Keamanan TI untuk para pegawai.

Untuk mengaplikasikan peran TI sebagai support, enabler, maupun business drivers pada pertahanan bisnis di Indonesia, disarankan menggunakan Model Peran TI terhadap Pertahanan Bisnis di Indonesia melalui Pengenalan dasar keamanan TI untuk para pegawainya. Model system Peran TI ini dapat dimulai dari pengembangan program kesadaran keamanan dilanjutkan perencanaan strategis kebijakan organisasi dan kepemimpinan tanggap darurat pemulihan. Untuk proses Teknik Pengamanan dasar dapat dilakukan penetration testing aplikasi dan berlanjut, penetration testing jaringan dan berlanjut, penetration testing perangkat mobile atau pertahanan dan nirkabel lanjutan serta analisa forensik serta Audit Peran TI terhadap pertahanan bisnis di Indonesia.

Apabila model system peran TI terhadap pertahanan Bisnis di Indonesia sudah dilakukan oleh para tim TI, maka berlanjut disarankan melaksanakan Model Pentahapan Kegiatan Peran TI terhadap pertahanan bisnis di Indonesia seperti gambar di bawah ini. 


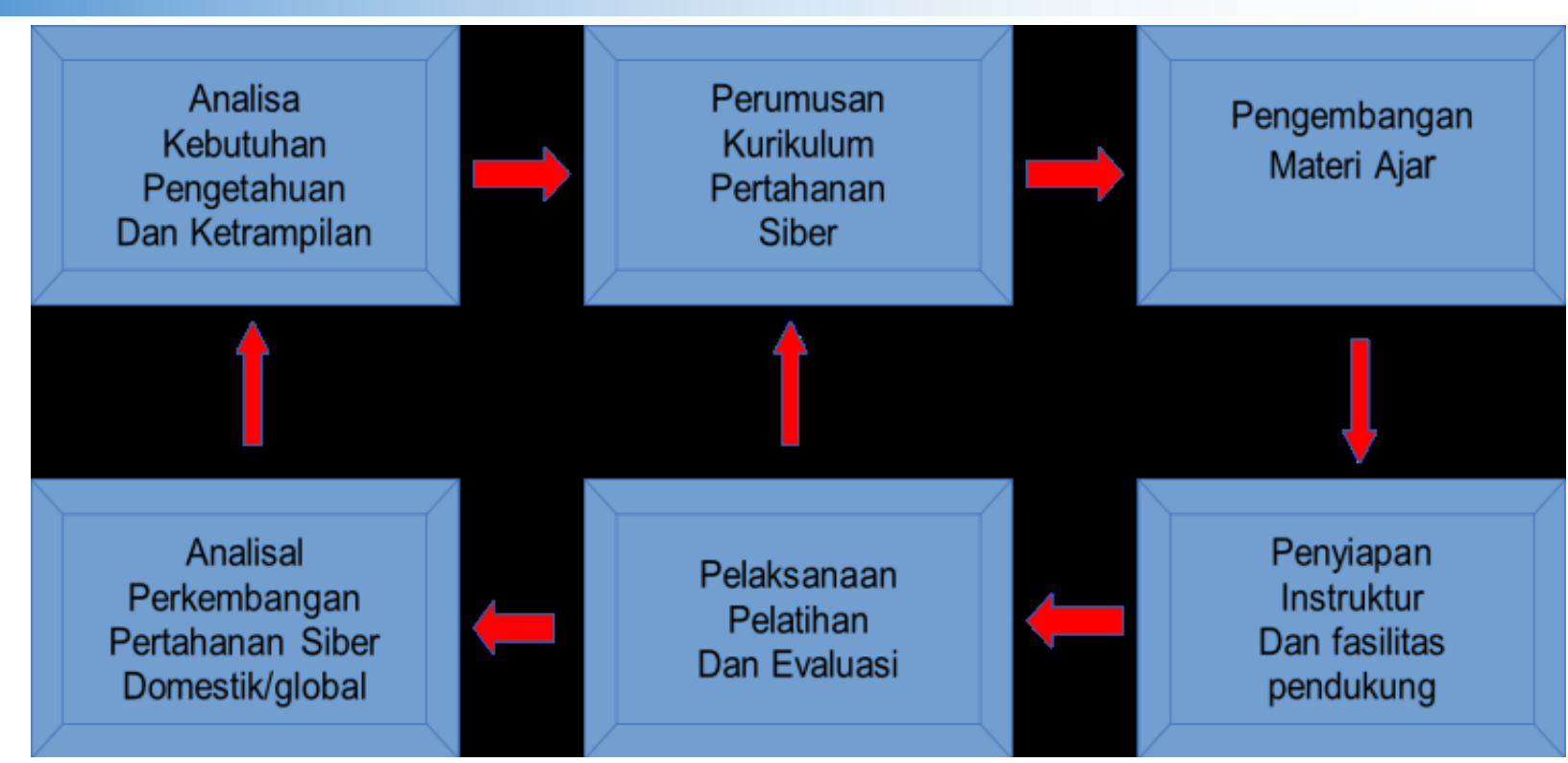

Gambar 2. Model Pentahapan Kegiatan Peran TI terhadap pertahanan bisnis di Indonesia

Aplikasi peran TI sebagai support, enabler, maupun business drivers pada pertahanan bisnis di Indonesia dapat disarankan melalui Model Pentahapan Kegiatan Peran TI terhadap pertahanan bisnis di Indonesia yang dimulai dari Penyiapan Instruktur dan Fasilitas pendukung pelatihan TI untuk Pertahanan Bisnis di Indonesia, Pelaksanaan Pelatihan dan Evaluasi pertahanan bisnis, Analisis perkembangan peran TI terhadap pertahanan bisnis domestic/global, analisis kebutuhan pengetahuan dan keterampilan peran TI terhadap bisnis di Indonesia, Perumusan kurikulum peran TI terhadap pertahanan bisnis di Indonesia dan Pengembangan materi Ajar.

\section{SIMPULAN DAN REKOMENDASI}

Teknologi informasi (TI) merupakan kebutuhan manusia yang sangat penting. Dengan TI manusia mampu melakukan sesuatu dengan lebih cepat, tepat dan efisien. TI dibutuhkan oleh anak-anak, remaja, dewasa dan orangtua. Saat ini TI tidak dapat dipisahkan dari individu dan kelompok ataupun organisasi. Hal ini terjadi karena nilai fungsional dari TI itu sendiri.

Pemerintah diharapkan dapat membantu pertumbuhan industri kreatif yang sedang berkembang pesat saat ini. Dengan demikian nilai fungsional TI menjadi sinkron dengan industri kreatif dan sektor ekonomi kreatif.

Aplikasi peran TI sebagai support, enabler, maupun business drivers pada pertahanan bisnis di Indonesia dapat disarankan melalui Model Pengenalan dasar keamanan TI untuk para pegawainya serta Model Pentahapan Kegiatan Peran TI terhadap pertahanan bisnis di Indonesia.

Penulis merekomendasi bahwa untuk merealisasikan kedua model tersebut sebaiknya dilakukan secara sinergi oleh tripple helix (Akademisi, Business, Government atau ABG) dalam mengembangkan industry kreatif seperti tersebut di atas agar peran TI terhadap pertahanan bisnis di Indonesia lebih meningkat secara komprehensif.

\section{DAFTAR PUSTAKA.}

Boisot, M. (1998). Knowledge Assets. Oxford : Oxford University Press.

Carr, J. (2009). Inside Cyber Warfare : Mapping the Cyber Underworld. O'Reilly Media.

Clarke, R. A., \& Knake, R. K. (2010). Cyber War. New York : Harper Colins.

Dr. Idwan Suhardi, Deputi Bidang Pendayagunaan dan Pemasyarakatan Iptek, Kementerian Negara Riset dan Teknologi, pada IPTEKVOICE yang disiarkan oleh Bahana 101.8 FM, Jum'at 19 Juni 2009, pukul 08.00-08.45 WIB 
Erbschloe, M. (2001). Information Warfare: How to Survive Cyber Attacks. New York: The McGraw-Hill.

Ghernaouti, S. (2009). Cybersecurity Guide for Developing Countries. Geneva : International Telecommunication Union.

Graham, J., Olson, R., \& Howard, R. (2009). Cyber Security Essential. Auerbach Publications.

Hartarini, Ayu. 2012, Peran Teknologi Dalam Industri Kreatif Indonesia

http://ayuhartarini.blogspot.com/2012/05/peran-teknologi-dalam-industri-kreatif.html. [14 Januari 2013] -http://en.wikipedia.org/wiki/Information_technology

Hutchinson, B., \& Warren, M. (2001). Information Warfare. Oxford : Butterworth-Heinemann.

Irawan, Herry. 2012, Peran Teknologi Dalam Industri Kreatif Indonesia [online].

http://www.scribd.com/doc/111544607/Peran-Teknologi-Informasi-Dalam-Industri-Kreatif. $\quad[14 \quad$ Januari 2013]

Kementerian Komunikasi dan Informatika RI. 2010, Buku Putih Kominfo. Jakarta: Kemkominfo.

Muhammad Shaukat, Muhammad Zafarullah. 2009, Impact of Information Technology on Organizational Performance: An Analysis of Qualitative Performance Indicators of Pakistan's Banking and Manufacturing Companies, European Journal of Economics, Finance andAdministrative Sciences.

Pangestu, Mari Elka. DR, Pengembangan Ekonomi Kreatif Indonesia 2025: Pengembangan Industri Kreatif Menuju Visi Ekonomi Kreatif Indonesia

Permenhan 84/2014. 2014, Pedoman Pertahanan Siber . Jakarta : Kementerian Pertahanan.

Ramalina Silaen. 2007, Peran Teknologi dalam Industri Kreatif Indonesia.

Ria. 2012, Industri Kreatif Butuh Peran Serta Pemerintah, [online]. Tersedia: http://www.teknopreneur.com/content/industri-kreatif-butuh-peran-serta-pemerintah.html. 6 Mei 2009.

Sri Utami, Setyaningsih. 2014, Pengaruh Teknologi Informasi Dalam Perkembangan Bisnis. 